\title{
Effect of Osmopriming Duration on Germination, Emergence, and Early Growth of Cowpea (Vigna unguiculata (L.) Walp.) in the Sudan Savanna of Nigeria
}

\author{
Ajit Singh, ${ }^{1}$ Rabi Dahiru, ${ }^{2}$ Mukhtar Musa, ${ }^{2}$ and Bello Sani Haliru ${ }^{2}$ \\ ${ }^{1}$ School of Biosciences, Faculty of Science, The University of Nottingham, Malaysia Campus, Jalan Broga, \\ 43500 Semenyih, Selangor, Malaysia \\ ${ }^{2}$ Department of Crop Science, Usmanu Danfodiyo University, Sokoto, PMB 2346, Sokoto, Nigeria
}

Correspondence should be addressed to Mukhtar Musa; mbmukhtar@gmail.com

Received 30 June 2013; Revised 31 December 2013; Accepted 14 January 2014; Published 27 February 2014

Academic Editor: Bernd Lennartz

Copyright (C) 2014 Ajit Singh et al. This is an open access article distributed under the Creative Commons Attribution License, which permits unrestricted use, distribution, and reproduction in any medium, provided the original work is properly cited.

\begin{abstract}
Seed osmopriming could be a sustainable method to increase crop establishment, uniform emergence, and growth of plant on the field. Laboratory and field studies were carried out in 2010 cropping season at Usmanu Danfodiyo University, Sokoto, to study the effect of seed osmopriming duration on the germination, emergence, and growth of cowpea seeds. Treatments consisted of

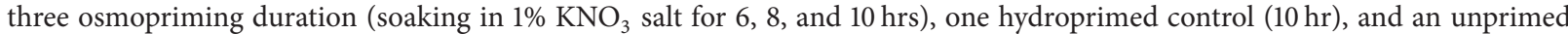
control. These five treatments were laid out in a completely randomized design (CRD) replicated four times. The results showed that osmopriming with $\mathrm{KNO}_{3}$ for different durations was at par but was superior to unprimed treatments in terms of seed germination, emergence, plant height, and dry matter accumulation at 3 weeks after sowing. From this study, it can therefore be concluded that seeds of cowpea could be primed (both hydro and osmopriming) for increased performance. However, osmopriming with $\mathrm{KNO}_{3}$ salt (soaked in $1 \% \mathrm{KNO}_{3}$ salt solution and dried before sowing) for 6 hours could result in greater seed germination and seedling height than hydropriming.
\end{abstract}

\section{Introduction}

Cowpea (Vigna unguiculata (L.) Walp.) is an important food crop in West Africa. It is often called as "poor man's meat" in this region where people cannot afford expensive animal protein. Cowpea is often recommended for pregnant and nursing mothers due to its high nutritional values. The ripe seed on average contains $22.0 \%$ protein, $1.4 \%$ fat, $59.1 \%$ carbohydrate, and $3.7 \%$ ash. The energy value is $1,420 \mathrm{k}$ (340 kcal) per $100 \mathrm{~g}$. Cowpea is the preferred pulse in large parts of Africa. The mature seeds are cooked and eaten alone or together with vegetable, spices, and often palm oil, to produce a thick bean soup which accompanies the staple food (cassava, yam plantain) [1].

Despite the immense importance of cowpea in our diet, the yield obtained by the farmers is low $0.26 \mathrm{tha}^{-1}$, [2]. One of the reasons contributing to low yield is poor crop establishment [3]. Good crop establishment seldom occurs in the marginal environment of the semi-Arid tropics due to unpredictable and erratic rainfall, poor soil, and low quality seed. Even where irrigation is possible, good crop establishment may still not be achieved $[4,5]$. This problem could, however, be addressed by seed priming. Seed priming is a procedure in which seed is soaked and then dried back to its original water content [3]; osmopriming simply means soaking seeds in osmotic solution [6]. Gurusinghe et al. [7] described seed priming as a technique of controlled hydration and drying that results in more rapid germination when the seed is reimbibed. Priming can be a valuable process for improving germination and uniformity of heterogeneously matured seed lots [8]. Seed priming has been successfully demonstrated to improve germination and emergence in seeds of many crops, particularly vegetables and small seeded grasses [9]. According to Bradford [9] and Taylor and Herman [10] seed priming is a presowing strategy for influencing seedling development by modulating pregermination 
metabolic activity prior to emergence of the radicle and generally enhances germination rate and plant performance. Fast germination and uniform emergence assist the farmer to "catch up" on the time lost to drought [11]. Work in Pakistan on seed of melon cultivar "Ravi" demonstrated that osmopriming with $1 \% \mathrm{KNO}_{3}$ resulted in increased seedling dry weight and increased number of pods compared with unprimed treatments [12].

Thus, this experiment was conducted to study the effect of seed osmopriming duration using $1 \% \mathrm{KNO}_{3}$ on the germination, emergence, and seedling growth of cowpea in a semiarid environment.

\section{Methodology}

For both germination and emergence tests, treatment consisted of three rates of osmopriming duration (soaking in

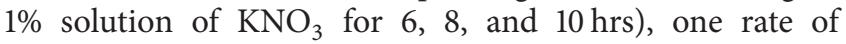
hydropriming (soaking in distilled water for $10 \mathrm{hrs}$ ), and a control (unprimed seed) laid out in a completely randomized design replicated four times.

2.1. Seed Germination. Cowpeaseeds of Cultivar 277-2 were sourced from Sokoto Agricultural Development Project (SADP). Osmopriming and hydropriming treatments were imposed in the night, a day prior to setting up the experiment as prescribed by the treatments (i.e., soaking in $1 \% \mathrm{KNO}_{3}$ solution for 6,8 , and $10 \mathrm{hrs}$ for osmopriming and soaking for $10 \mathrm{hrs}$ in distilled water for hydropriming). At the time of experiment, the temperature of the $\mathrm{KNO}_{3}$ solution and natural water during priming was $29^{\circ} \mathrm{C}$ and the environmental temperature was $30^{\circ} \mathrm{C} .1 \% \mathrm{KNO}_{3}$ solution was prepared by diluting $10 \mathrm{~g}$ of $\mathrm{KNO}_{3}$ with $1000 \mathrm{~mL}$ (1 litre of water) and $200 \mathrm{~mL}$ of the solution was used to soak 400 seeds for each treatment. After priming seeds were removed, air-dried for 2 hours, and treated with seed treatment chemical (Apron Star $42 \mathrm{WS}$ containing: $20 \% \mathrm{w} / \mathrm{w}$ thiamethoxam, $20 \% \mathrm{w} / \mathrm{w}$ metalaxyl-M, and $2 \% \mathrm{w} / \mathrm{w}$ difenoconazole) at the rate of one sachet (10 g) per $4 \mathrm{~kg}$ of seed to avoid any seed borne infection during the experiment. Seed germination test was carried out in the Crop Science Laboratory, Usmanu Danfodiyo University, Sokoto. Four replicates of 100 seed were placed on the Whitman's filter paper in Petri dishes with $8 \mathrm{~cm}$ diameter. Water was poured regularly on the filter paper to ensure adequate moisture for seed germination. Data were collected on germination from day one to the fifth day after sowing and on percentage germination. A seed was considered germinated when the radicle emerged through the seed coat. Germination percentage was computed using the following formula:

$$
\text { Germination percentage }=\frac{\text { Total seeds germinated }}{\text { Total seeds sown }} \times 100 \text {. }
$$

2.2. Field Emergence. The emergence test was carried out in the rainy season in the Biological Science Garden of Usmanu Danfodiyo University, Sokoto $\left(13^{\circ} 01^{\prime} \mathrm{N}\right.$ and $15^{\circ} 13^{\prime} \mathrm{E}$, about
$350 \mathrm{~m}$ above sea level) in the Sudan Savanna Agroecology with annual rainfall ranging from 500 to $800 \mathrm{~mm}$ per annum.

The experimental site was prepared manually using hand hoe and leveled using a rake. Twenty (20) beds of $30 \times 30 \mathrm{~cm}$ each were constructed. Sowing was done on July 21, 2010, in rows by drilling 100 seeds at a depth of $1-2 \mathrm{~cm}$ in a sandy soil. Soil temperature at sowing to emergence ranged from 32 to $34^{\circ} \mathrm{C}$ and atmospheric temperature ranged from 30 to $32^{\circ} \mathrm{C}$. No fertilizer or irrigation was applied during the experiment. Data were collected on emergence of seedling on the first, second, and third day after sowing only due to limitation of resources. This was done by counting the number of seedlings that emerged out of the soil. Data was also collected on the seedling height and dry matter accumulation at 3 weeks after sowing (WAS). Five plants were sampled and used for both seedling height and dry matter accumulation. Seedling height was measured using a meter rule from the base of the plant to the growing tip of the plant and dry matter accumulation was obtained by harvesting the plant at 3 WAS and oven-drying at $65^{\circ} \mathrm{C}$ to constant weight. The percentage seedling emergence was computed using the following formula:

$$
\text { Emergence percentage }=\frac{\text { Total seeds emerged }}{\text { Total seeds sown }} \times 100 \text {. }
$$

The data collected on seed germination, emergence, seedling height, and dry matter accumulation were subjected to analysis of variance (ANOVA) procedure for completely randomized design (CRD) using SAS 2003 software [13]. Mean separation was carried out using least significant difference test (LSD).

\section{Results and Discussions}

3.1. Seed Germination. Seed priming treatments led to significant differences in cowpea germination on days 1 and 2, as well as in total germination (Table 1), while on days 3, 4 , and 5 no significant differences were observed (Table 1). On day 1 after sowing, osmoprimed seeds had significantly higher germination than unprimed and hydroprimed seeds, while on day 2, germination of seeds osmoprimed for $10 \mathrm{hrs}$ was significantly higher than other treatments, and the least was recorded with unprimed seeds. Osmoprimed seeds had higher total germination $(79.00,75.00$, and $81.00 \%$ for 6 , 8 , and $10 \mathrm{hrs}$ of priming, resp.) than either hydroprimed (66.00\%) or unprimed seeds (53.00) (Table 1). The differences in germination on day 1 between osmoprimed and other treatments were not surprising. Such differences were the expected result of earlier activation of physiological processes of germination in primed seeds that resulted in improved germination through activation and softening of the seed coat. Also, final germination of all osmoprimed seeds was significantly higher than either hydroprimed or unprimed seeds. Use of $\mathrm{KNO}_{3}$ salt may have supplied $\mathrm{NO}_{3}$ to the seed and also caused exosmosis that resulted in removal of germinationinhibiting substances. This result was similar to work by Gurusinghe et al. [7], where radical tip cells of some tomato seed lots advanced through the cell cycle during priming. In this study this was evident on day 2, when primed seeds 
TABLE 1: Effect of osmopriming duration on germination of cowpea seeds.

\begin{tabular}{|c|c|c|c|c|c|c|c|}
\hline \multirow{2}{*}{ Priming treatment } & \multirow{2}{*}{ Priming duration (hrs) } & \multicolumn{5}{|c|}{ Number of seeds germinated } & \multirow{2}{*}{ Total \% } \\
\hline & & $1 \mathrm{DAS}$ & 2 DAS & 3 DAS & 4 DAS & $5 \mathrm{DAS}$ & \\
\hline Unprimed & (0) & $0.00^{\mathrm{b}}$ & $10.75^{\mathrm{c}}$ & 13.00 & 20.50 & 10.00 & $53.00^{\mathrm{d}}$ \\
\hline Hydropriming & 10 & $2.00^{\mathrm{b}}$ & $21.25^{\mathrm{ab}}$ & 11.50 & 19.50 & 11.50 & $66.00^{c}$ \\
\hline Osmopriming & 6 & $11.25^{\mathrm{a}}$ & $21.00^{\mathrm{ab}}$ & 16.50 & 18.00 & 12.50 & $79.00^{\mathrm{ab}}$ \\
\hline Osmopriming & 8 & $11.50^{\mathrm{a}}$ & $18.50^{\mathrm{b}}$ & 13.25 & 19.75 & 12.00 & $75.00^{\mathrm{b}}$ \\
\hline Osmopriming & 10 & $10.75^{\mathrm{a}}$ & $24.00^{\mathrm{a}}$ & 15.25 & 18.50 & 12.50 & $81.00^{\mathrm{a}}$ \\
\hline SE & & 0.987 & 1.440 & 1.434 & 0.834 & 1.025 & 1.524 \\
\hline Significance & & * & * & ns & ns & ns & * \\
\hline
\end{tabular}

Means in a column followed by same letters are not significance different using LSD test. ${ }^{*}$ Significant at 5\% level; ns: not significant; DAS: day(s) after sowing.

TABLE 2: Effect of seed osmopriming duration on emergence of cowpea seedlings.

\begin{tabular}{|c|c|c|c|c|c|}
\hline \multirow{2}{*}{ Priming treatment } & \multirow{2}{*}{ Priming duration (hrs) } & \multicolumn{3}{|c|}{ Emergence } & \multirow{2}{*}{ Total (\%) } \\
\hline & & 1 DAS & 2 DAS & 3 DAS & \\
\hline Unprimed & $(0)$ & $7.25^{\mathrm{b}}$ & 17.50 & 19.50 & $44.25^{\mathrm{c}}$ \\
\hline Hydropriming & 10 & $13.50^{\mathrm{a}}$ & 19.50 & 18.00 & $51.00^{\mathrm{b}}$ \\
\hline Osmopriming & 6 & $15.25^{\mathrm{a}}$ & 19.50 & 18.50 & $53.50^{\mathrm{ab}}$ \\
\hline Osmopriming & 8 & $13.75^{\mathrm{a}}$ & 20.00 & 19.25 & $53.00^{\mathrm{ab}}$ \\
\hline Osmopriming & 10 & $14.00^{\mathrm{a}}$ & 20.50 & 20.75 & $55.25^{\mathrm{a}}$ \\
\hline SE & & 1.337 & 0.834 & 0.677 & 1.281 \\
\hline Significance & & $*$ & ns & ns & * \\
\hline
\end{tabular}

Means in a column followed by same letters are not significantly different using LSD test. ${ }^{*}$ Significant at $5 \%$ level; DAS: day(s) after sowing.

TABLE 3: Effect of osmopriming duration on the height and dry matter accumulation of cowpea seedling at 3 weeks after sowing.

\begin{tabular}{lccc}
\hline Priming treatment & Priming duration $(\mathrm{hrs})$ & Seedling height at 3 WAS $(\mathrm{cm})$ & Dry matter accumulation at 3 WAS $(\mathrm{g})$ \\
\hline Unprimed & $(0)$ & $11.98^{\mathrm{c}}$ & $0.50^{\mathrm{b}}$ \\
Hydropriming & 10 & $16.23^{\mathrm{b}}$ & $2.06^{\mathrm{a}}$ \\
Osmopriming & 6 & $21.48^{\mathrm{a}}$ & $2.81^{\mathrm{a}}$ \\
Osmopriming & 8 & $21.60^{\mathrm{a}}$ & $2.25^{\mathrm{a}}$ \\
Osmopriming & 10 & $20.65^{\mathrm{a}}$ & $2.73^{\mathrm{a}}$ \\
SE & & 1.074 & 0.284 \\
Significance & & $*$ & $*$ \\
\hline
\end{tabular}

Means in a column followed same letter are not significantly different using LSD. ${ }^{*}$ Significant at $5 \%$ level; WAS: week(s) after sowing.

germinated faster than unprimed seeds. The results agree with those of [14], who reported faster and higher total germination of sorghum using $\mathrm{KNO}_{3}$ solution.

3.2. Seedling Emergence. As with germination, hydro- and osmopriming improved the emergence speed on day 1 and led to significantly higher total emergence over the unprimed (control) (Table 2). However, no significant differences were observed between osmoprimed and hydroprimed seeds. According to Singh et al. [14], stand establishment determines plant density, uniformity, and management options. Other sources have also reported that seed emerged faster and more completely following simple, overnight, on-farm priming techniques [11].

3.3. Seedling Growth. Results indicated a significant effect of priming on seedling height and dry matter accumulation at three weeks after sowing (Table 3). Plant height significantly increased following osmopriming for 6,8 , and 10 hours and was the highest followed by hydropriming for 10 hours and the least was recorded with unprimed (control). Similarly, dry matter accumulation following all priming treatments was significantly higher than unprimed seeds. These results indicated the potential for better seedling field performance under abiotic stress conditions. The difference could be due to faster germination and emergence recorded with primed seeds. Similar conclusions were reported by Ashraf and Rauf [15], who stated that primed corn seeds under environmental stress had a better chance for producing a good crop with higher economic yield. Likewise earlier work on cowpea in the same environment [16] recommended six hours of priming for the best performance of the crop.

\section{Conclusions}

In conclusion, the study performed on cowpea suggested that cowpea seeds can be primed (both hydro- and osmopriming) 
for increased germination and field performance. However, osmopriming with $1 \% \mathrm{KNO}_{3}$ salt for 6 hours could result in greater seed germination and seedling height than hydropriming.

Recommendations. Further research is needed to osmopriming of cowpea seeds with $1 \% \mathrm{KNO}_{3}$ salt for shorter durations of 2 and 4 hrs.

\section{Conflict of Interests}

The authors of this paper have no financial relation whatsoever that can lead to conflict of interests.

\section{References}

[1] T. Vanderborght and J. P. Baudoin, "(Vigna unguiculata) (L) Walpers," in Crop Production in Tropical Africa, H. R. Romain, Ed., pp. 334-348, DGIC Belgium, 2001.

[2] FAOSTAT Data, "Food and agricultural organizations statistics," 2007, http://faostat3.fao.org/home/index.html.

[3] D. Harris, "On-farm seed priming to increase yield of crops and reduce risk of crop failure in marginal areas of developing countries," in Proceedings of the 2nd international Agronomy Congress on Balancing Food and Environmental Security, A containing challenge [Extended Sumaries], pp. 1509-1511, New Delhi, India, 2002.

[4] D. Harris, "Staying in control of rainfed crops," in Proceedings of the 1st Annual Scientific Conference of the SADCC/ODA Land and Water Management Programme, pp. 257-262, Gaborone, Botswana, 1992.

[5] D. Harris, "The effects of manure, genotype, seed priming, depth and date of sowing on the emergence and early growth sorghum bicolor (L.) Moench in semi-arid Botswana," Soil and Tillage Research, vol. 40, no. 1-2, pp. 73-88, 1996.

[6] C. A. Parera and D. J. Cantliffe, "Presowing seed priming," Horticultural Reviews, vol. 16, pp. 109-114, 1999.

[7] S. H. Gurusinghe, Z. Cheng, and K. J. Bradford, "Cell cycle activity during seed priming is not essential for germination advancement in tomato," Journal of Experimental Botany, vol. 50, no. 330, pp. 101-106, 1999.

[8] M. O. Oluoch and G. E. Welbaum, "Effect of postharvest washing and post-storage priming on viability and vigour of sixyear-old muskmelon (Cucumis melo L.) seeds from eight stages of development," Seed Science and Technology, vol. 24, no. 2, pp. 195-209, 1996.

[9] K. J. Bradford, "Manipulation of seed water relations via osmotic priming to improve germination under stress condition," Hort Science, vol. 21, pp. 1105-1112, 1986.

[10] A. G. Taylor and G. E. Herman, "Concepts and technologies of seed treatments," Annual Review of Phytology, vol. 28, pp. 321$339,1990$.

[11] D. Harris, B. S. Raghuwanshi, J. S. Gangwar et al., "Participatory evaluation by farmers of on-farm seed priming in wheat in India, Nepal and Pakistan," Experimental Agriculture, vol. 37, no. 3, pp. 403-415, 2001.

[12] M. Farooq, S. M. A. Basra, N. Ahmed, and B. A. Saleem, "Osmopriming improves the germination and early seedling growth of melons (Cucumus melo L.)," Pakistan Journal of Agricultural Sciences, vol. 44, p. 3, 2007.
[13] SAS (Statistical Analysis System), "SAS Release 9.1 for Windows," SAS Institute Inc, Cary, NC, USA, 2003.

[14] A. Singh, R. Dahiru, and M. Musa, "Osmopriming duration influence on germination, emergence and seedling growth of sorghum," Seed Technology, vol. 34, no. 1, pp. 111-118, 2012.

[15] M. Ashraf and H. Rauf, "Inducing salt tolerance in maize (Zea mays L.) through seed priming with chloride salts: growth and ion transport at early growth stages," Acta Physiologiae Plantarum, vol. 23, no. 4, pp. 407-414, 2001.

[16] A. Singh, A. H. Abubakar, H. G. Ahmed et al., "Seed hydropriming effects on germination, emergence and growth of cowpea (Vigna unguiculata L. Walp," Trends in Advanced Science and Engineering, vol. 1, no. 3, pp. 37-42, 2011. 


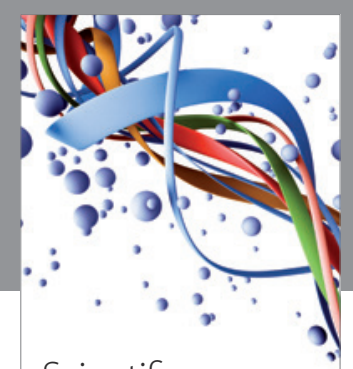

Scientifica
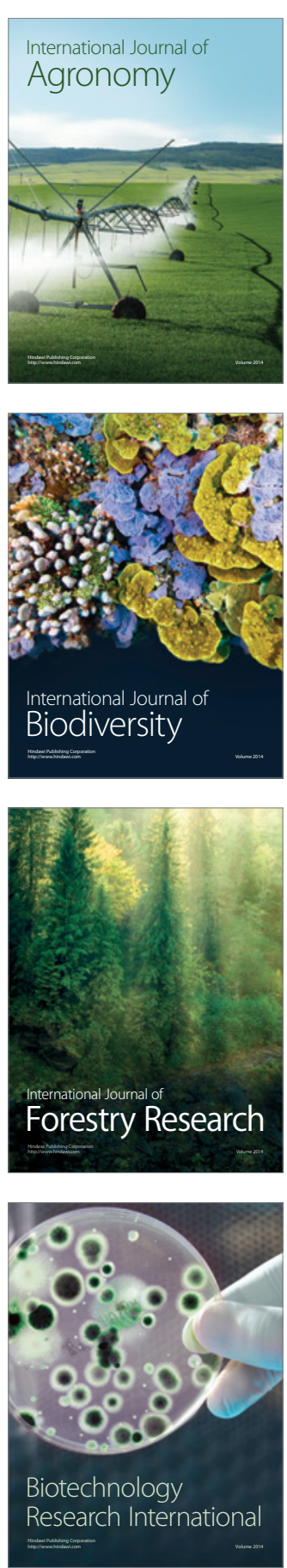
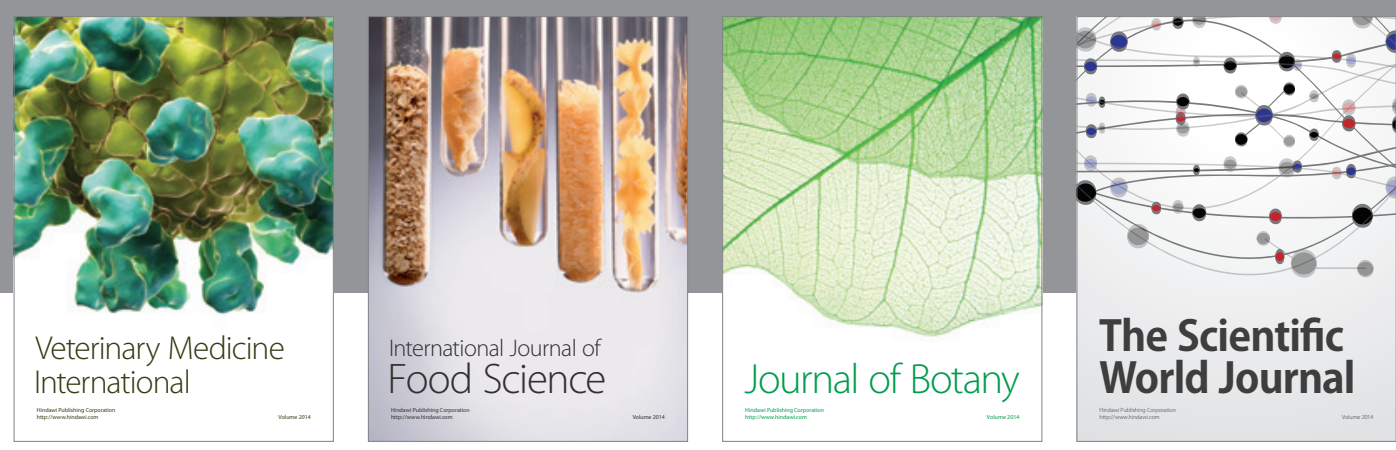

The Scientific World Journal
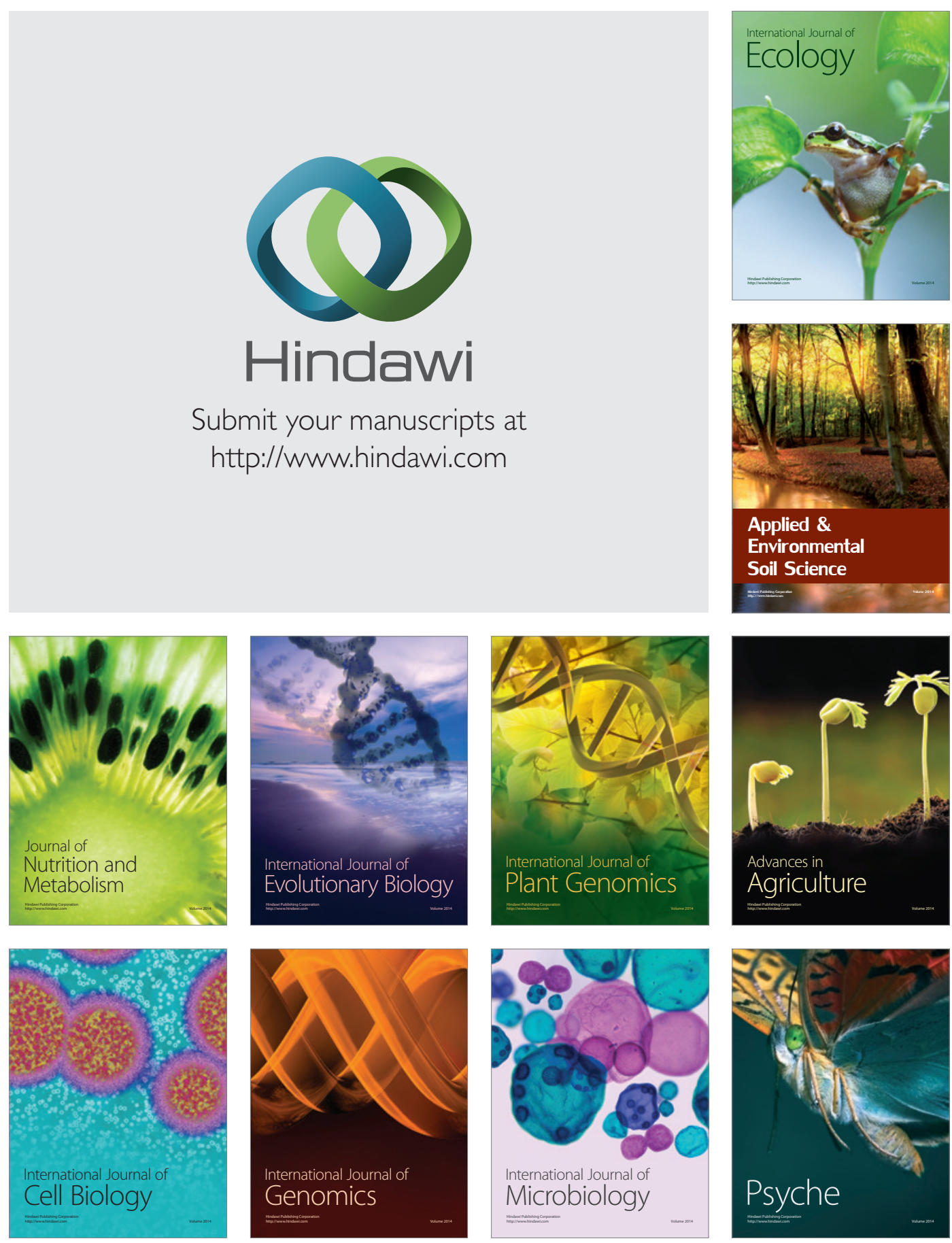